\title{
METAMORPHOSIS OF PUERTA TIERRA FROM CADIZ (SPAIN) IN THE 18TH CENTURY AS A PARADIGM OF MODERN FORTIFICATION
}

\author{
F-R. Lozano-Martínez ${ }^{1, *}$, F. Arévalo-Rodríguez ${ }^{2}$, G. Granado-Castro ${ }^{1}$ \\ ${ }^{1}$ Dept. of Graphic Engineering, Higher Technical School of Building Engineering, University of Seville - (ramonlozano, \\ ggranado)@us.es \\ ${ }^{2}$ Department of Architectural Graphic Expression, Higher Technical School of Architecture. University of Seville - farevalo@us.es
}

\author{
Commission II - WG II/8
}

KEY WORDS: Puerta Tierra, Cadiz, Bastioned Fortification, Glacis, Military Engineers

\begin{abstract}
:
The city of Cadiz, located in a peninsula, was initially defended by its only land access through a wall of land extended from coast to coast across the isthmus; this access was erected at the beginning of the 16th century. After being devastated by an Anglo-Dutch attack in 1596 (where they had access by this flank), Felipe II decided to rebuild the city and this defensive element. Furthermore, after the Spanish War of Succession, Puerta Tierra [Land Gate] experienced a considerable metamorphosis that would complete its integration in the first quarter of the 18th century, becoming now a complete defensive system that would protect one of the most important squares of the Kingdom of Spain. In this sense, this work can be considered one of the most representative examples of the application of military treatises based on the ideas developed by the French marshal Vauban and applied by the Spanish engineer Ignacio Sala. This research focuses on the defensive elements whose works, which were developed between approximately 1730 and 1760, involved large earthworks and an intensive use of the oyster stones, resulting in the final configuration of the work. The analysis developed below is based on the plans prepared by the Spanish engineers involved in this construction.
\end{abstract}

\section{MANUSCRIPT}

\subsection{Introduction}

Cadiz is located at the end of a long isthmus that connects the city with Isla de Leon and, therefore, with the rest of the province of Cadiz. For the city, the defensive aspect was always very important because, though the environment has very steep terrain that is difficult to access from a boat, it has two easily accessible areas such as the inner bay (at the east of the city where the Port is located now) and the Southern beach, Santa Catalina.

The city always lived under threat, as corroborated by the numerous attacks suffered throughout history, mainly due to two factors: on the one hand, the magnificent strategic location near the Strait of Gibraltar; on the other hand, as soon as the Casa de Contratacion was moved from Seville in 1717, the city centralized the trading with America, becoming the gateway to all the wealth that financed the needs of the Kingdom during the Modern Age (Arévalo Rodríguez, 2013). In response to these threats and after its evolution throughout the Modern Age, the city would eventually become one of the greatest places of the Kingdom of Spain (Fernández Cano, 1973). All this effort turned the city into a defensive belt surrounded by walls, castles and bulwarks, being Puerta Tierra a prominent place that protected the city access by land. This work focuses the attention on that evolution along the 18th century.

Puerta Tierra was meant not only to defend the east side of the city from the land access, but it also played an important part in the defence system of the bay, together with the Fort of San Lorenzo de Puntales and the Castle of Santa Catalina; the

defensive triangle was supplemented with other elements such as the Castle of San Sebastián or the Fort of San Luis (Figure 1).

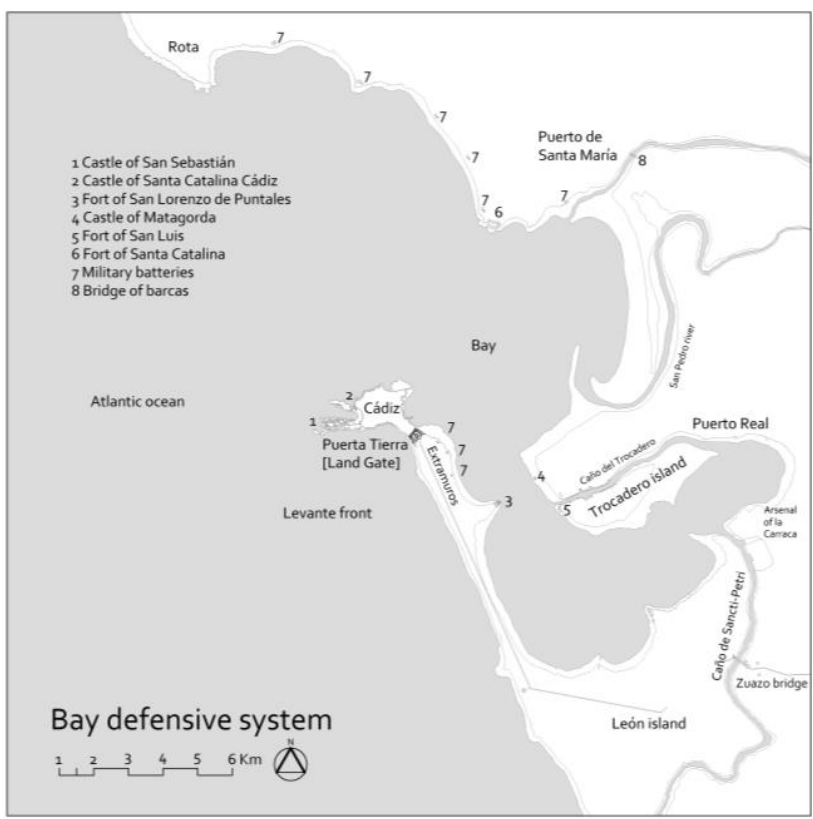

Figure 1. Location of Land Front with respect to the city of Cadiz and its bay. Own elaboration.

\footnotetext{
* Corresponding author
} 


\subsection{Evolution before the 18th century}

The first representation of the city is dated from 1513, with anonymous authorship (Figure 2). It represents Cadiz at the end of the Middle Ages: the castle, the perimeter wall and the outer suburbs, but no trace of the ground wall (Navascués, de Palacio, 1996).

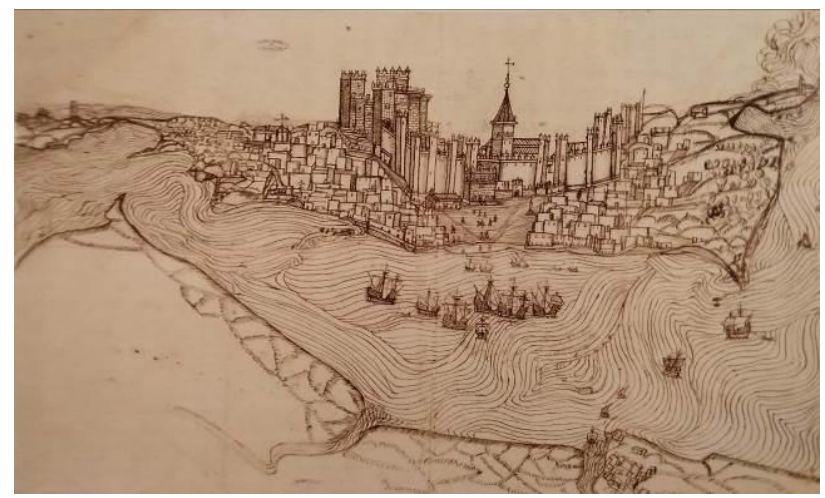

Figure 2. Drawing of the city of Cadiz on a shutter that they have opened in the fortress and on the wall, 1513.

Anonymous. AGS. Chamber of Castile, Villages, 00004, 361. Document symbol: MPD, 25, 047.

Subsequently, this wall does appear represented in the view taken by Georg Hoefnagel in 1564, consisting of a wall of crenelated ground, with a central bulwark with artillery pieces on the side, representing an access door to the city (Figure 3).

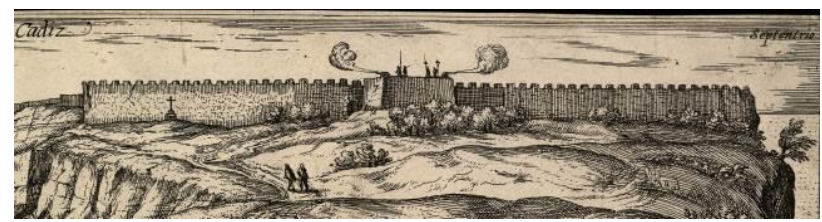

Figure 3. Detail of the representation of Georg Hoefnagel where the earth wall is observed, 1564. Civitatis Orbis

Terrarum (Cartographic and Geological Institute of Catalonia).

In following stages, the front was evolving thanks to the work developed by some Italian engineers. In this way, Juan Bautista Calvi began the implementation of the bulkwarked system in the middle of the 16th century by projecting two semi-forts in the two ends of the wall, which would be constructed of ground and fagina, a bundle of very thin branches that gives consistency to the embankment (Ortega Feliu, Aladro Prieto, 2012). The half-bulwark on the bay side was named Santa Elena, and the one in front of the Atlantic Ocean was named San Roque. Among all the engineers with an important role in these works, we can highlight Tiburcio Espanoqui (Spanish name), who pictured the state of the front in 1587. The drawing shows the wall with a semi-bulwark in every end, an open pit extended from coast to coast before them and finally a covered path as the most distant element. It is dated from 1587 (Figure 4) and shows a defensive front not finished yet, even though it was meant to be implemented in 1578 (Fernández Cano, 1973).
The ineffectiveness of this defensive front was verified in 1596 when an Anglo-Dutch alliance destroyed it in such a way that Felipe II questioned its reconstruction. However, he could not afford this idea in order not to give the impression of a decadent king who could not defend his cities. Therefore, apart from the city, he decided to rebuild the wall and to reinforce the two semi-bulwarks (Fernández Cano, 1973, p. 51).

As a result of these works and the construction of different defensive elements - walls, bulwarks and castles - all along the perimeter of the city, a second attack in 1625 was repelled even though, among other elements, the works in Puerta Tierra were not completed (Garófano-Sánchez, 2012, p. 34).

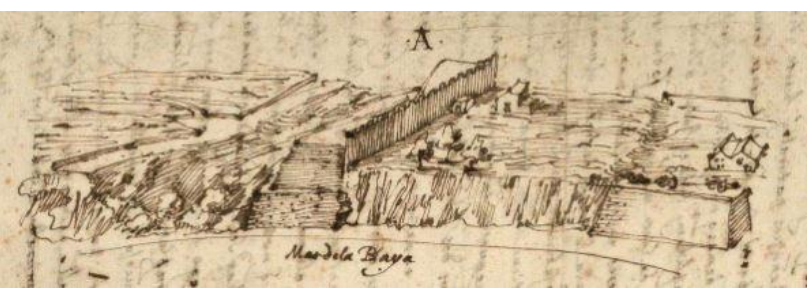

Figure 4. Bay Sea. Puerta Tierra drawing by Tiburzio Spannocchi in 1587. AGS. Secretary of War, File, 03352, 90, signature: $1587-S G U$.

In the middle of the 17th century, the governor Count of Molina ordered to cover the exterior face of the walls with coats of stone and lime since the ground crumbled with the rain (Retegui Bensusan \& Imp. Jiménez-Mena, 1976). The state of the fortification on these days can be clearly seen in a representation of the city plan included in the Atlas of the Marquis of Heliche (Sánchez Rubio et al., 2004) (Figure 5).

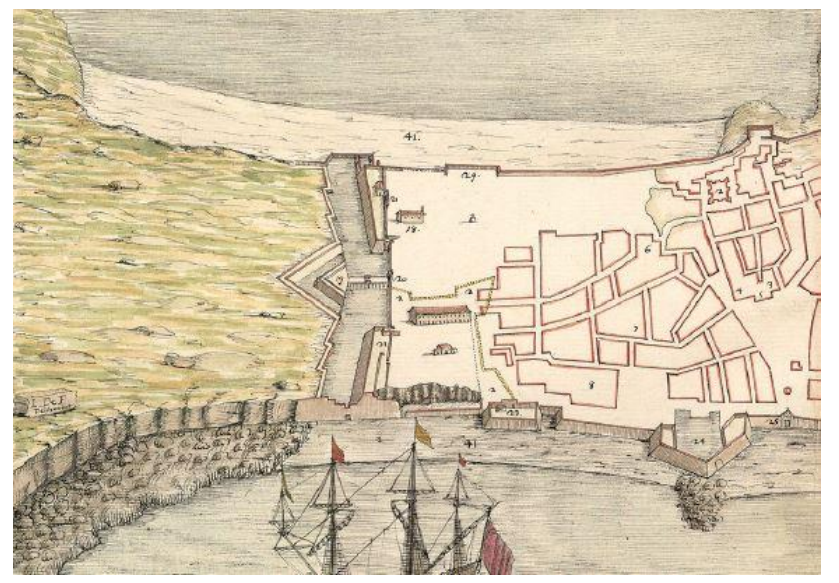

Figure 5. Detail of the Puerta Tierra in the representation of the Cadiz plant, between 1650 and 1655, belonging to the collection of plants of Spanish cities of the Marquis de Heliche.

Among all the improvements that were made in the front after the Anglo-Dutch attack, the highlight is a new advanced front that was named "Crowned Work", because of the similarity with a crown; it is composed of a central bulwark and two outer semi-bulwarks joined by two walls or curtains. The execution of this new element was completed in 1671 (Garófano-Sánchez, 2012); we can perfectly observe its configuration in the Arámburu View (Figure 6). 


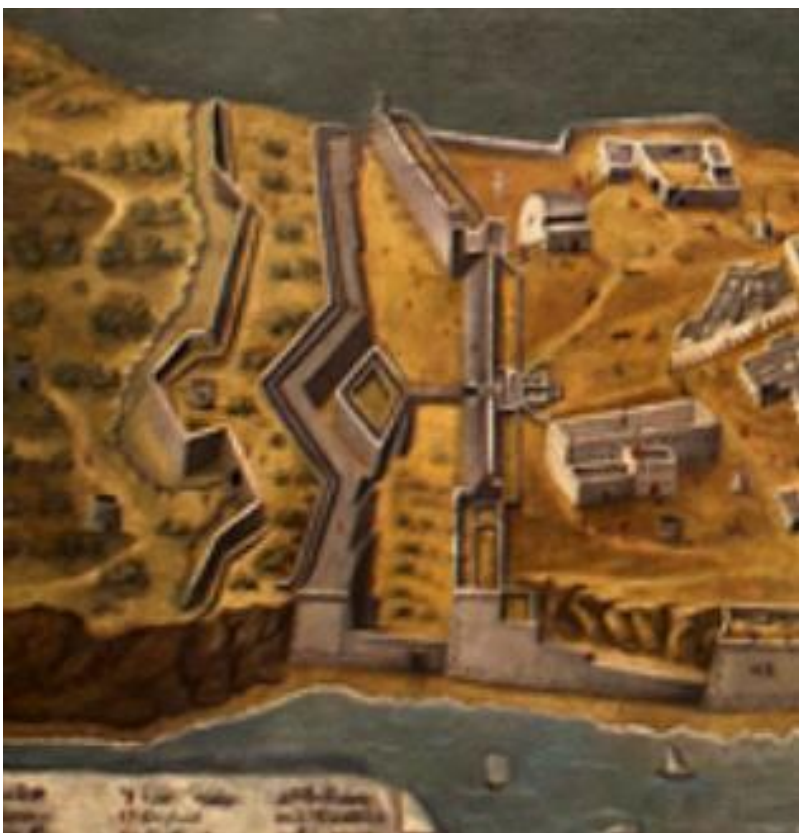

Figure 6. Detail of the one known as "Vista Arámburu" where the fortification of the Land Front appears with the "Work crowned" in a view of Cadiz from the end of the 17th century. Anonymous. Museum of the Cortes of Cadiz.

\subsection{Two projects for the metamorphosis of Puerta Tierra in the 18th century}

With the Spanish Succession War that extended from 1701 to 1713 , the Bourbon dynasty occupied the Spanish throne. The will to review and fortify the city of Cadiz finally arrived with the new airs of progress that they brought to the country, also because there was a fear of new attacks on the city ${ }^{1}$. Meanwhile, King Felipe V approved the creation of the Spanish Military Engineers Corps in 1711, through the initiative of General Engineer Prospero Verboom. This Corps had a fundamental role in the modernization of the country and its work had an important impact on the improvement of the defensive system of Cadiz (Capel Sáez et al., 1988).

The engineer Jorge Prospero Verboom developed a first architectural project of Puerta Tierra (Figure 7) based on how Cadiz was in 1724, which did not changed a lot since the construction of the Crowned Work. In fact, this defensive element was preserved in this first project, being the main novelties the expansion of the small central ravine, the demolition of the current covered path behind the pit and its replacement by a new one that included two main squares. The Crowned Work remained, having the defects repaired. One of these works was to reconstruct its central bulwark by slightly modifying its design, changing the angles between flanks; the same happened to the ends that reached the two banks. Ahead of this, on the outer esplanade, the construction of two counterguards was designed to protect the curtains of the Crowned Work. Finally, distant from the city, the project included the construction of a covered walkway that included a single main square with a set of elements that connected the natural terrain through the glacis.

1 In August 1702, under the command of Admiral Sir George Rooke and the Duke of Ormond, an Anglo-Dutch fleet was presented off the coast of Cadiz requesting its adhesion to the cause of the Austrian archduke and not achieving it, he went on to assault and loot Rota, El Puerto de Santa María and Puerto Real (Garófano-Sánchez 2012, p. 59)

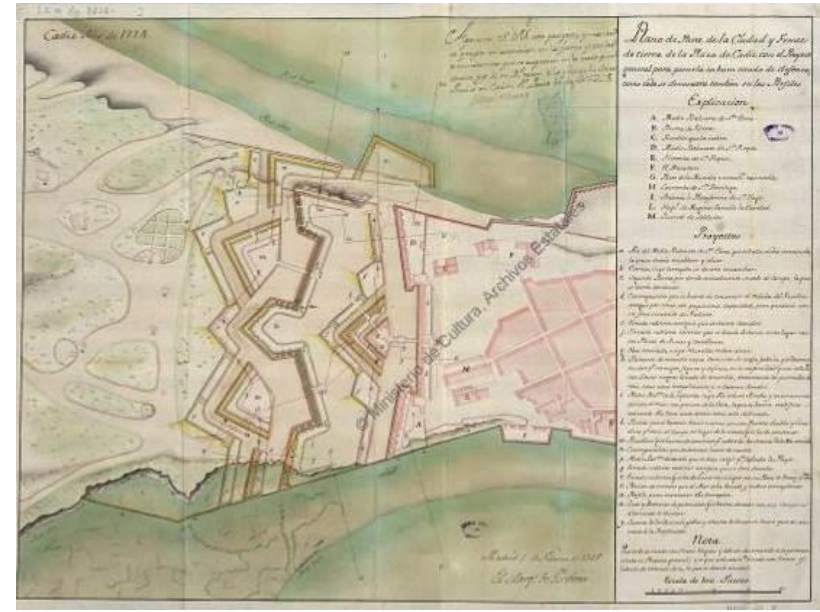

Figure 7. General project "to put in good condition" the Puerta Tierra over Cadiz in 1724. Year 1728. Marquis of Verboom. AGS, Secretary of War, file, 03626. Signature MPD, 29,008.

The king approved the implementation of the project in 1728 , though not many works were carried out then because this project led to a second and final one prepared by Ignacio Sala under the supervision of Prospero Verboom. This change was mainly due to the poor state of the Crowned Work, regarding both the factory and the foundation; that would lead to a new reconstruction that was not viable economically (Ortega Feliu 2012 , p. 227-228). Both the first and the second projects considered the construction of one bulwark on Santa María beach that was very close to San Roque to defend that beach. However, this element was never built.

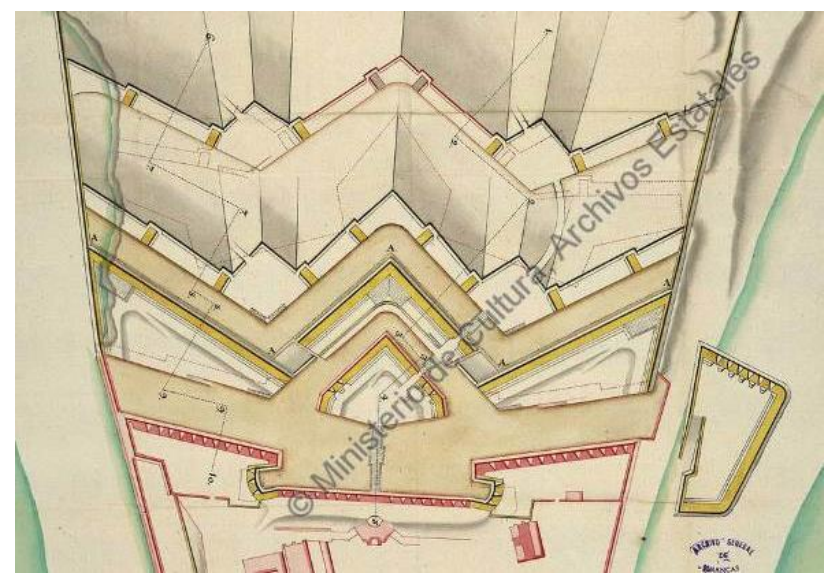

Figure 8. Detail of the project for the Land Front of the Plaza de Cadiz, September 12, 1730. Ignacio Sala. AGS. Secretary of War, file, 03626. Signature MPD, 05,184.

The second and final project made many changes over the first one (Figure 8). It was carried out by the chief engineer in Cadiz at that time, Ignacio Sala, approved by the king in 1731. What essentially characterizes this new project is the total demolition of the Crowned Work, replacing it with three counterguards, one central and two practically symmetrical at the extremes that were extended to the coast. Before them, another covered walkway was added, made of a continuous layout that was parallel to the three counterguards located in the place previously occupied by the Crowned Work. Finally, as a more advanced element of the front, a second covered walkway was projected. At the time of its construction, it was possible to take advantage of the central area once located there before. 


\subsection{Materialization of the definitive Land Front.}

In 1727 the King created an administrative body that was in charge of supervising the construction of new defensive elements and repairing those already existing. This was made in both the perimeter wall of the city and in the Land Front. This body was named the Royal Fortification Board. Once every work was finished, it came under the control of the Ministry of War. (Garófano-Sánchez 2012, p. 63). In order to perform this function, the engineers in charge of the works of Land Front, provided the Royal Board the first days of every year with plans that reflected both the current state of the Front and the works that had been carried out during the immediately preceding year.

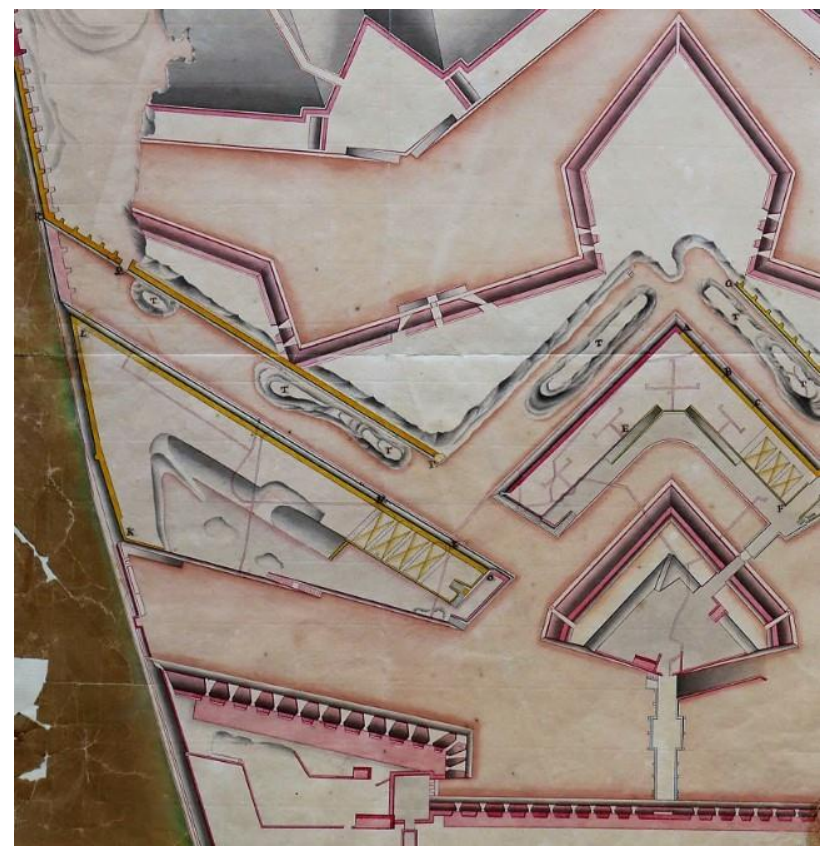

Figure 9. Detail of the plan that shows the state of the

Fortifications of the Puerta Tierra of Cadiz, on January 1, 1746. Everything washed in yellow indicates the portion of work done during the year 1745. Municipal Historical Archive of Cadiz.

The plan represented in Figure 9 corresponds to the state of Puerta Tierra on January 1st, 1746 and therefore, represents the works carried out in 1745 . We can observe there the earthworks for the construction of the counterguard of Santa Elena, as well as the first four vaults, coloured in yellow. On the other hand, in front of the counterguard with the letter " $\mathrm{T}$ " there are excavations that are being made to make the pits.

From the compilation of these plans, a bar chart has been made to show the temporal evolution of the works of Puerta Tierra. To simplify the representation and facilitate its analysis we have grouped the works in four different zones identified by colours in Figure 10.

If we analyse the bar chart in Figure 10, we observe how the works corresponding to the definitive project extended practically from 1730 to 1760 : the works corresponding to the semi- bulwarks of Santa Elena and San Roque, as well as the curtain, lasted for five years from 1730; in 1747, an isolated repair was carried out; the last four years correspond to the repair and rework of the outer wall of San Roque bulwark. Some damages were common and frequent in all the defensive elements that fought the sea in the front of Levante (east side).
The expansion works of the central ravine lasted only one year, while the three new counterguards required twelve years.

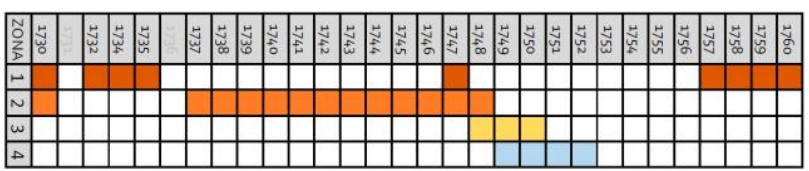

Figure 11. Bar diagram of the execution of four differentiated zones of the Land Front. Own elaboration.

Right after finishing the three counterguards, the construction of the two covered walkways began, overlapping these works with the construction of the glacis one year later.

This research is focused on the defensive elements that make up the Land Front. No elements of any other functionality have been considered, such as the pavilions that were built behind the curtain and semi-bulwarks, whose construction work combined from 1749 to 1760 .

We can see the final result of all this evolution of the Land Front and the rest of the defensive belt surrounding the city perimeter in three dimensions and with a high degree of details. This was indicated by Granado-Castro in the model that represents the city as of 1779 (Granado-Castro, MartínPastor, 2016), which is located in the Museum of the Cortes of Cadiz; we can see a detail of the city focused on Land Front in Figure 12.

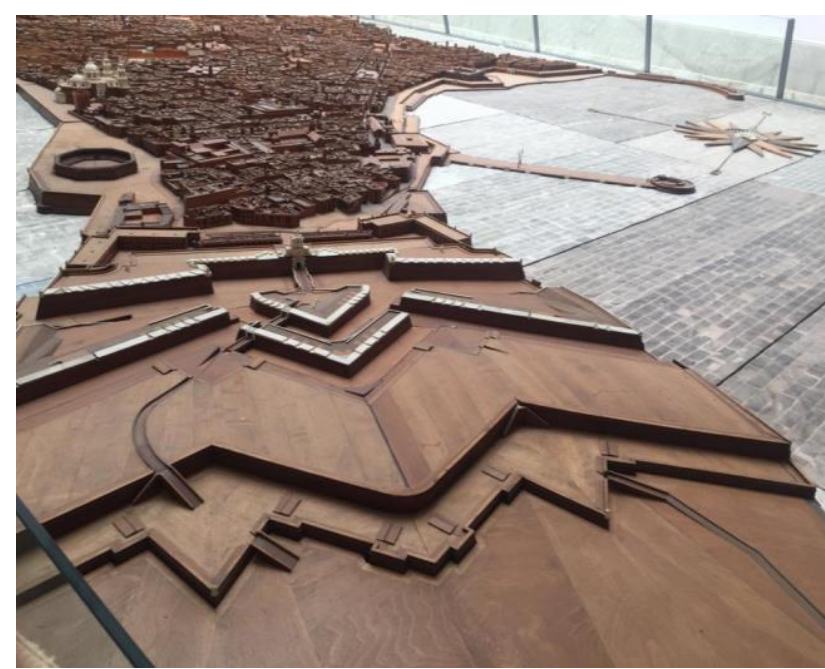

Figure 12. Photograph of the Land Front area of the Cadiz model as of 1779. Museum of the Cortes de Cadiz. Photograph by F. Arévalo-Rodríguez.

\subsection{Materials and constructive techniques.}

The construction of Puerta Tierra took from the $16^{\text {th }}$ to the $18^{\text {th }}$ century. During such a long time, there was an important change in the materials and constructive techniques used. When the work started at some time between 1513 and 1564 (Granado-Castro et al., 2016, p. 2), they alternated ground coat and fajina (very thin branches tied together) in order to give consistency to the wall (De Rojas, 1598, p. 38). However, these walls came down with the rain (Retegui Bensusan, 1976), so the external side had to be coated with stones and lime between 1650 and 1660 (Fernández Cano, 1973, p. 93). The walls of all the defensive elements related to Puerta Tierra were made up mainly of ground and oyster stones. 

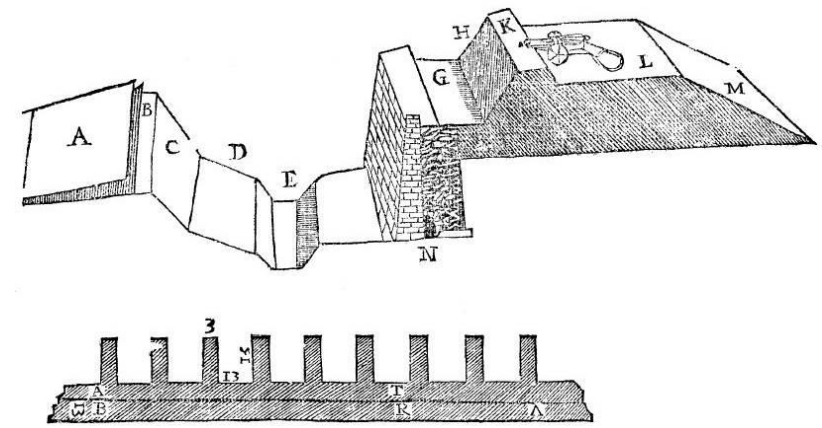

Figura 13. Imagen del "Capítulo XV. Para faber el grueffo q hade tener la muralla de piedra, ò ladrillo ${ }^{2}$, y los terraplenos, la altura de la muralla, y los demás requifitos neceffarios". Theory and practice of fortification, regarding the measures and defence at the time, split in three different parts... by Captain Christoval de Rojas (1598).

Cristobal de Rojas was the chief engineer from 1596 and he presented his constructive techniques in a treatise (De Rojas, 1598, p. 69), as seen in Figure 13. This was only one of the many fortification treatises during those three centuries, what does not mean that they all were strictly followed. In other words, many of those treatises were written after the construction experience; as an example, the design of the Crowned Work $(1656$ - 1750) did not match exactly any of those previous designs that appear in the more relevant treatises of that period (Lozano-Martínez et al., 2017, p. 5-6). There are many plans about all the works made by those engineers in charge of the big alterations projected by Ignacio Sala in 1728; all these plans help to understand what and how they were building Puerta Tierra, as seen in Figure 14.

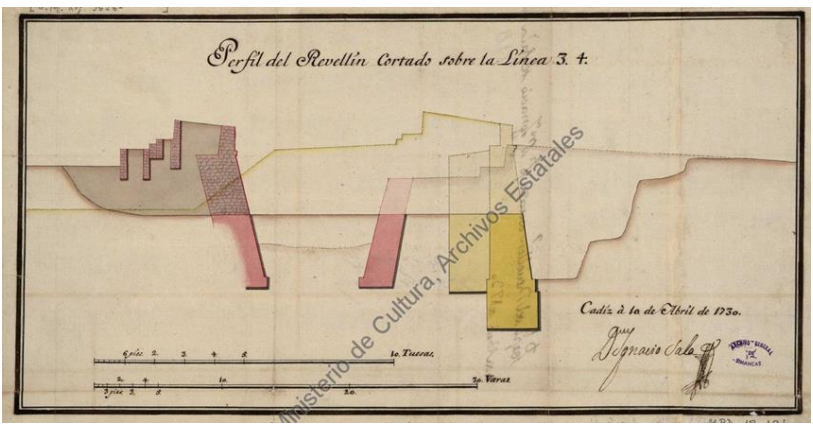

Figure 14. Plan of one section of the ravine projected by Ignacio Sala, AGS. Secretariat of War, Legajos, 03626.

\section{CONCLUSIONS}

The works of the fortification of the front of Puerta Tierra lasted around 200 years. During this period there was an evolution that, as a result of this study, can be divided into two different stages, both of them based on the currents of thought on treatises and the fortification techniques at that time.

2 Cristobal de Rojas considered different options when thinking about the way a canyon ball would affect the stretch of the wall. One of the best options is the one presented in Puerta Tierra: an embankment behind a wall made up of mortar, which is composed of lime, sand and rubble; the inconveniences of this Wall was the high cost and that it took a long time in "enxugarfe" (setting the cement). (De Rojas, 1598, p. 70-71).
The first stage was developed under the treatise and fortification techniques related to the Italian military engineering; it took from the first half of the 16th century to the beginning of 18 th century. This stage was characterized by plain designs and materials that helped to change from the old ground wall with a central bastion, to a pit followed by a hornwork; however, this work could not resist the AngloDutch attack in 1596. For this reason, the front was reinforced with a ravine ahead of the pit, that had to be expanded, and a covered walkway. Afterwards, they added a double hornwork or crowned work, finished by 1671 .

The second stage started when the Bourbons arrived to the Spanish Court, because they introduced the French fortification system. This new system used more elaborated elements which required harder work and more money. At the beginning, some elements from the Italian school were not demolished because the idea was to use the existing defensive elements and to reinforce them with some other new. However, it was not possible to adapt the crowned work because the cost was unaffordable due to the bad general situation and the design faults. They designed then a second project to demolish this work, and they included some new elements ahead of hornworks and of the central ravine created in the Italian period.

Later on, some engineers such as Silvestre Abarca, Juan Caballero, Juan Martin Zermeño y Jose Barnola designed some other projects that were never carried out. The priority in Cadiz was to close the defensive belt that was properly settled, but couldn't be better improved because the ravages of the sea on the wall were very expensive to maintain.

Therefore, it can be seen as a non-definitive and unfinished work because the reign had so many expensive fronts opened, that they could not afford more money to this work.

\section{REFERENCES}

Arévalo Rodríguez, F., 2013. Territorial defence in the province of Cadiz since the Discovery of America. The evolution of the borders and the architectural models. In En Tejedor Cabrera y Linares Gómez del Pulgar, 2013 Fortified places in the Bay of Cadiz. Parma: Festival Architettura. ISBN 9788889739228 .

Capel Sáez, H., Sánchez, J. E., Moncada, O., 1988. De Palas a Minerva: la formación científica y la estructura institucional de los ingenieros militares en el siglo XVIII. Serbal.

Fernández Cano, V., 1973. Las defensas de Cádiz en la Edad Moderna [Escuela de Estudios Hispanoamericanos].

Garófano-Sánchez, R., 2012. Cádiz amurallada. Su registro fotográfico. Quorum,.

Granado-Castro, G., \& Martín-Pastor, A., 2016. The 3d ModelMap of Cadiz (1779): A Unique Project of Cartography in Modern Spain. Cartographic Journal, 53(3), 268-281. https://doi.org/10.1080/00087041.2016.1149263

Navascués y de Palacio, J., 1996. Cádiz a través de 1513 (Apuntes para su arquitectura y urbanismo desde el siglo XIII). Colegio Oficial de Arquitectos de Andalucía Occidental, Demarcación de Cádiz. 
The International Archives of the Photogrammetry, Remote Sensing and Spatial Information Sciences, Volume XLIV-M-1-2020, 2020 HERITAGE2020 (3DPast | RISK-Terra) International Conference, 9-12 September 2020, Valencia, Spain

Ortega Feliu, P., Aladro Prieto, J. M., 2012. Guía de las fortificaciones y sistemas de defensa de la bahía de Cádiz. Colegio Oficial de Arquitectos de Cádiz.

Retegui Bensusan, M. de., Imp. Jiménez-Mena., 1976. Cádiz y sus famosas murallas bocetos de estudio, vida e historia (2a ed.).

Sánchez Rubio, R., Testón Núñez, I., Sánchez Rubio, C. M., 2004. Imágenes de un Imperio Perdido. El Atlas del Marqués de Heliche. Plantas de diferentes Plazas de España, Italia, Flandes y las Indias. Junta de Extremadura. Badajoz. 